\title{
Carbohydrate Content and Enzymic Activities in the Membrane of Spiroplasma citri
}

\author{
By ITZHAK KAHANE, SARIT GREENSTEIN \\ AND SHMUEL RAZIN \\ Biomembrane Research Laboratory, Department of Clinical Microbiology, \\ The Hebrew University-Hadassah Medical School, Jerusalem, Israel
}

(Received 6 January 1977; revised 25 March 1977)

\section{INTRODUCTION}

The spiroplasmas constitute a newly discovered group of wall-less prokaryotes, resembling mycoplasmas in morphology of colonies, ultrastructure, filtrability, requirement for cholesterol, absolute resistance to penicillin and low guanine and cytosine content of cellular deoxyribonucleic acid. Actively growing spiroplasma cultures differ from those of classical mycoplasmas in being composed mostly of long helical filaments which have a screw-like rotational and flexional movement (Cole et al., 1973). Our previous investigation (Razin et al., I973) showed that the cell membrane of $S$. citri can be readily isolated by osmotic lysis of the organisms. In gross chemical composition and ultrastructure it resembled the cell membrane of the classical mycoplasmas. The purpose of the present investigation was to provide more information on the enzymic activities and carbohydrate moieties of the $S$. citri membrane.

\section{METHODS}

Organisms and membranes. Spiroplasma citri (Morocco strain, ATCC27556) was grown in the medium of Saglio et al. (1973) and Acholeplasma laidlawii (oral strain) in modified Edward medium (Razin \& Rottem, 1976). Both media were supplemented with $5 \%(\mathrm{v} / \mathrm{v})$ horse serum. The organisms were harvested, washed and osmotically lysed as described previously (Razin et al., 1973; Razin \& Rottem, 1976). The membranes were separated from the cytoplasmic fluid at $4{ }^{\circ} \mathrm{C}$ by centrifugation at $32000 \mathrm{~g}$ for $30 \mathrm{~min}$, and were washed once in water and suspended in a small volume of $\beta$-buffer (Razin \& Rottem, 1976 ) diluted $\mathrm{I}: 20$ in deionized water.

Binding of lectins. Wheat germ agglutinin (WGA), Ricinus communis agglutinin (RCA) and concanavalin A (ConA) were isolated, purified and iodinated, and their binding to membranes was estimated as described by Kahane \& Tully (1976). In general, ${ }^{125} \mathrm{I}$-labelled lectins (Io $\mu \mathrm{g}$ ) were incubated for $\mathrm{I}_{5} \mathrm{~min}$ at $37^{\circ} \mathrm{C}$ with membrane suspension ( $400 \mu \mathrm{g}$ protein in $0.4 \mathrm{ml} 0.05 \mathrm{M}-\mathrm{Tris} / \mathrm{HCl}, \mathrm{pH} 7.2$ ). The membranes were washed three times in the same buffer and their radioactivity was estimated. Specific displacement of membrane-bound lectins by simple sugars was tested by incubating the labelled membranes for $\mathrm{I} \mathrm{h}$ at $37^{\circ} \mathrm{C}$ in $0.1 \mathrm{M}$ solutions of $N$-acetyl-D-glucosamine, D-galactose or $\alpha$-methyl-D-mannoside for WGA, RCA and ConA, respectively. Non-specific displacement of these lectins by sugars was tested by the same procedure, but using $\mathrm{D}$-galactose, $\alpha$-methyl-D-mannoside and $N$-acetyl-D-glucosamine for WGA, RCA and ConA, respectively (Kahane \& Tully, 1976).

Analytical procedures. Protein was determined according to Lowry et al. (195I). Carbohydrates were analysed by gas-liquid chromatography (Packard, model 7300) using a $3 \%$ SE-30 column $(2.5 \mathrm{~m} \times 3.2 \mathrm{~mm}$ diam.) as described by Clamp (1974). Hexosamines were also determined in the amino-acid analyser (Spiro, 1972). Enzymic activities were measured as described by Ne'eman \& Razin (1975). NADH oxidase (EC I .6.99.3) activity was measured spectrophotometrically by following the decrease in absorbance at $340 \mathrm{~nm}$ on addition of NADH to the reaction mixture. Results were expressed as decrease in absorbance at $340 \mathrm{~nm}$ (mg protein) $)^{-1} \mathrm{~min}^{-1}$. Adenosinetriphosphatase (EC 3.6.I .3) activity was measured by following the release of inorganic phosphate from ATP. Results were expressed as $\mu \mathrm{mol}$ inorganic phosphate released (mg protein $)^{-1}(30 \mathrm{~min})^{-1} \cdot p$-Nitrophenylphosphatase activity was measured spectrophotometrically by determining the intensity of the yellow colour of the liberated $p$-nitrophenol. The reaction mixture $(\mathrm{I} \cdot \mathrm{O} \mathrm{ml}) \mathrm{con}-$ sisted of $100 \mathrm{~mm}-\mathrm{Tris} / \mathrm{HCl}, \mathrm{pH} \mathrm{7.6,5} \mathrm{mM}-\mathrm{MgCl}_{2}$, Io mM-p-nitrophenylphosphate and $400 \mu \mathrm{g}$ membrane 
protein. The reaction was stopped after 30 or $60 \mathrm{~min}$ incubation at $37^{\circ} \mathrm{C}$ by adding $2 \mathrm{ml} 0.5 \mathrm{M}$-Tris (not neutralized) in $5 \%(\mathrm{w} / \mathrm{v})$ trichloroacetic acid. The precipitate was removed by centrifuging and the intensity of the yellow colour in the supernatant fluid was determined at $420 \mathrm{~nm}$. Results were expressed as increase in absorbance at $420 \mathrm{~nm}$ (mg protein) $)^{-1} \mathrm{~h}^{-1}$. Ribonuclease and deoxyribonuclease activities were determined by measuring the absorbance at $260 \mathrm{~nm}$ of soluble nucleotides released from the nucleic acids. Results were expressed as increase in absorbance at $260 \mathrm{~nm}(\mathrm{mg} \text { protein })^{-1}(6 \mathrm{~min})^{-1}$.

\section{RESULTS AND DISCUSSION}

\section{Carbohydrates in membranes}

The presence of hexosamines in S. citri membranes has been reported by us (Razin et al., 1973) and confirmed by Bebear et al. (1974). In the present study we tried to determine whether the hexosamines form a polymer of the kind found in A. laidlawii (Gilliam \& Morowitz, 1972) or whether they are attached to other membrane components. The absence of a polyhexosamine polymer in S. citri is indicated by our finding that the hexosamines could not be concentrated by extraction of the membranes with $75 \%(\mathrm{v} / \mathrm{v})$ aqueous ethanol and precipitation with acetone, according to the method of Gilliam \& Morowitz (1972). Moreover, the quantities of glucosamine and galactosamine detected in $S$. citri by the amino-acid analyser varied quite markedly in different batches of membranes and were only about one-eighth to one-third of those found associated with $A$. laidlawii membranes. The glucosamine content of $S$. citri membranes ranged from 3.6 to $7.8 \mu \mathrm{g}$ (mg protein) ${ }^{-1}$, and that of galactosamine ranged from $\mathrm{I} \cdot 9$ to $5.3 \mu \mathrm{g}$ (mg protein) ${ }^{-1}$. The addition to $250 \mathrm{ml}$ of $S$. citri growth medium of $5 \mu \mathrm{Ci}$ of $\left[\mathrm{II}^{14} \mathrm{C}\right]$ glucosamine $\left(58 \mathrm{mCi} \mathrm{mmol}{ }^{-1}\right)$ or $\left[\mathrm{I}^{14} \mathrm{C}\right.$ ]galactosamine $\left(5 \mathrm{I}^{\circ} 4 \mathrm{mCi} \mathrm{mmol}^{-1}\right)$ resulted in slight radioactive labelling of the membranes. The values ranged from 500 to 700 c.p.m. (mg protein) ${ }^{-1}$, compared with 4000 to 9600 c.p.m. (mg protein) $)^{-1}$ in membranes of $A$. laidlawii grown in the same medium. The hexosamine content of $S$. citri membranes was not affected by the removal of membrane lipids by extraction with chloroform/methanol $(2: \mathrm{I}, \mathrm{v} / \mathrm{v})$. However, proteolytic digestion of membrane proteins decreased the hexosamine content, particularly glucosamine, in proportion to the release of membrane proteins. Thus, the release of about $55 \%$ of membrane proteins by pronase caused a decrease of $45 \%$ of the glucosamine and about $20 \%$ of the galactosamine content of the membranes.

Lectins were used to detect exposed carbohydrate residues on the S. citri membrane. Substantial amounts of ConA and RCA were bound to the membranes (Table I). The specificities of the binding, measured by their displacement with specific sugars, were $94.5 \%$ and $99 \%$, respectively. Only about $10 \%$ of the bound lectins were displaced by the nonspecific sugars. Carbohydrate analysis indicated the presence in the membranes of the sugars specific for the lectins, suggesting that at least some of these sugars are exposed on the membrane surface. Although the membranes contained $N$-acetylglucosamine, there was no binding of WGA, the lectin specific for this sugar. Treatment of S. citri membranes with proteolytic enzymes markedly decreased the lectin binding (Table I). The decrease in binding of both RCA and ConA was proportional to the loss of protein and corresponded to the decrease in carbohydrate residues from the membranes (Table I). On the other hand, small amounts of WGA did bind to the membranes after proteolysis. The amount of WGA bound after removal of $45 \%$ of the membrane proteins was greater than that bound to membranes from which $70 \%$ of the proteins had been removed. In the first case the $\mathrm{N}$-acetylglucosamine content of the membrane was not affected, but the more extensive digestion removed almost $75 \%$ of this sugar (Table I).

The binding of lectins to $S$. citri membranes indicates that some of their mannose, glucose and galactose residues are exposed on the membrane surface, while the $N$-acetylglucosamine residues are masked in native membranes. The partial removal of membrane proteins by proteolysis exposes some of the $N$-acetylglucosamine residues to WGA. More extensive proteolysis decreases the hexosamine residues and WGA binding. Whereas proteolysis of 
Table I. Effect of proteolytic treatment on the binding of lectins and the carbohydrate content of $S$. citri membranes

Membranes were digested with $2 \mu \mathrm{g}$ pronase $\mathrm{ml}^{-1}$ for $30 \mathrm{~min}$ or with $50 \mu \mathrm{g}$ trypsin $\mathrm{ml}^{-1}$ for $2 \mathrm{~h}$ at $37^{\circ} \mathrm{C}$. For measurement of lectin binding, ${ }^{125} \mathrm{I}$-labelled lectins ( $\mathrm{IO} \mu \mathrm{g}$ ) were incubated with membranes ( $400 \mu \mathrm{g}$ protein) and the amount of bound lectin was determined as described in Methods. Carbohydrates were estimated by the method of Clamp (1974): Fuc, fucose; Man, mannose; Gal, galactose; Glc, glucose; GlcNAc, $N$-acetylglucosamine; GalNAc, $N$-acetylgalactosamine.

\begin{tabular}{|c|c|c|c|}
\hline Proteolytic treatment & None & Pronase & Trypsin \\
\hline $\begin{array}{l}\text { Protein released }(\%) \\
\text { Lectin bound }(\%)\end{array}$ & 0 & 45 & 70 \\
\hline $\begin{array}{l}\text { WGA } \\
\text { RCA } \\
\text { ConA }\end{array}$ & $\begin{array}{c}0 \\
30 \cdot 9 \\
43 \cdot 3\end{array}$ & $\begin{array}{r}I \cdot 9 \\
2 I \cdot 2 \\
28 \cdot 8\end{array}$ & $\begin{array}{r}0.8 \\
14.6 \\
9.4\end{array}$ \\
\hline \multicolumn{4}{|c|}{ Carbohydrate [nmol (mg protein $\left.)^{-1}\right]$} \\
\hline Fuc & $?^{*}$ & 0 & 0 \\
\hline Man & 27 & 12 & 6 \\
\hline Gal & 27 & $2 \mathrm{I}$ & I4 \\
\hline Glc & 24 & 27 & $2 i$ \\
\hline GlcNAc & 7 & 7 & 2 \\
\hline GalNAc & trace & trace & 0 \\
\hline
\end{tabular}

* Minor peak, close but apparently not identical to that of fucose.

Mycoplasma and Acholeplasma membranes usually increased their lectin-binding capacity, suggesting that binding sites are glycolipids or other protease-resistant compounds (Kahane \& Tully, 1976), the progressive digestion of S. citri membrane proteins resulted in a proportional decrease in the lectin-binding sites (Table I), suggesting that most of the carbohydrate residues in the $S$. citri membrane are attached to protein. Glycoproteins are not common constituents of the plasma membrane of prokaryotes (Razin, 1975). Among mycoplasmas, however, they have been detected in $M$. pneumoniae (Kahane \& Marchesi, 1973) and $M$. gallisepticum (Goel \& Lemcke, I975). Our results suggest that glycoproteins are also present in $S$. citri membranes. However, we failed to detect glycoproteins in $S$. citri by electrophoresis in sodium dodecyl sulphate-polyacrylamide gels stained with the periodic acid-Schiff reagent. This failure may be due to the fact that the staining procedure we followed (Segrest \& Jackson, 1972) is most effective with glycoproteins containing sialic acid (I. Kahane, unpublished results) which is apparently absent from $S$. citri membranes (Table I). Nevertheless, the possibility that the carbohydrate moieties in $S$. citri membranes are part of other macromolecules, loosely attached to the membrane proteins and released following the removal of these proteins, cannot be ruled out.

\section{Enzymic activities}

The localization of several enzymic activities in cell fractions of $S$. citri and A. laidlawii are compared in Table 2 . In general, the specific activities were lower in $S$. citri, particularly those of the $p$-nitrophenylphosphatase. As in $A$. laidlawii and in all other mycoplasmas tested so far (Razin, 1975), the $S$. citri adenosinetriphosphatase activity was localized in the membrane. It could not be released by washing the membranes in buffers of decreasing ionic strength, with or without ethylenediaminetetraacetate, according to the method used by Ne'eman \& Razin (1975). Hence, the adenosinetriphosphatase of $S$. citri appears to be an integral membrane enzyme. It thus resembles the adenosinetriphosphatase of $M$. mycoides subsp. capri and of $A$. laidlawii, and differs from the adenosinetriphosphatases of the wallcovered bacteria which behave like peripheral membrane proteins in being released with low-ionic strength buffers and ethylenediaminetetraacetate (Razin, I975). As in the sterolrequiring Mycoplasma species, but unlike Acholeplasma species (Razin, 1975), the NADH oxidase activity was localized in the cytoplasmic fraction of $S$. citri, suggesting the presence 
Table 2. Localization of enzymic activities in $S$. citri and $A$. laidlawii cell fractions

Data are expressed as specific activities, as defined in Methods.

$\begin{array}{lccccc}\quad \text { Preparation } & \begin{array}{c}\text { Adenosine- } \\ \text { triphosphatase }\end{array} & \begin{array}{c}\text { NADH } \\ \text { oxidase }\end{array} & \begin{array}{c}p \text {-Nitrophenyl- } \\ \text { phosphatase }\end{array} & \text { Ribonuclease } & \begin{array}{c}\text { Deoxyribo- } \\ \text { nuclease }\end{array} \\ \begin{array}{l}\text { S. citri } \\ \text { Membranes }\end{array} & 2.30 & 0.03 & 0.17 & 1.30 & 0.62 \\ \quad \text { Cytoplasmic fluid } & 0.15 & 0.62 & 0.00 & 0.66 & 0.00 \\ \begin{array}{l}\text { A. laidlawii } \\ \text { Membranes }\end{array} & 7.80 & & & & \\ \text { Cytoplasmic fluid } & 0.02 & 0.02 & 6.00 & 7.70 & 1.34 \\ & & & 0.15 & 3.90 & 4.02\end{array}$

of a truncated electron transport system in spiroplasmas. Another interesting difference between $S$. citri and $A$. laidlawii was the absence of detectable deoxyribonuclease activity in the cytoplasmic fraction of $S$. citri (Table 2). The presence of NADH oxidase activity in the cytoplasm, the requirement for cholesterol (Freeman et al., I976, Saglio et al., I973) and the inability to synthesize fatty acids from acetate (Freeman et al., I976; S. Razin \& S. Greenstein, unpublished data) place $S$. citri closer to the Mycoplasma than to the Acholeplasma species.

We wish to thank A. Amar for his help with the lectin-binding experiments. The work was supported in part by a grant to I.K. from the B. De Rothschild Foundation for the Advancement of Science in Israel.

\section{REFERENCES}

Bebear, C., Latrille, J., Fleck, J., Roy, B. \& Bové, J. M. (1974). Spiroplasma citri: un mollicute. Colloques de l'Institut National de la Santé et de la Recherche Médicale 33, 35-42.

Clamp, J. R. (1974). Analysis of glycoproteins. Biochemical Society Symposia 40, 3-I6.

Cole, R. M., Tully, J. G., Popkin, T. J. \& Bové, J. M. (I973). Morphology, ultrastructure, and bacteriophage infection of the helical mycoplasmalike organism (Spiroplasma citri gen.n., sp.n.) cultured from 'stubborn' disease of citrus. Journal of Bacteriology 115, 367-386.

Freeman, B. A., Sissenstein, R., McManus, T. T., Woodward, J. E., Lee, I. M. \& Mudd, J. B. (I976). Lipid composition and lipid metabolism of Spiroplasma citri. Journal of Bacteriology $\mathbf{1 2 5}$, 946-954.

Gilliam, J. M. \& Morowitz, H. J. (1972). Characterization of the plasma membrane of Mycoplasma laidlawii. IX. Isolation and characterization of the membrane polyhexosamine. Biochimica et biophysica acta 274, 353-363.

Goel, M. C. \& LeMCKe, R. M. (I975). Dissociation of Mycoplasma gallisepticum membranes with lithium diiodosalicylate and isolation of a glycoprotein. Annales de Microbiologie (Institut Pasteur) 126 B, 299-3I2.

Kahane, I. \& Marchesi, V. T. (I973). Studies on the orientation of proteins in mycoplasma and erythrocyte membranes. Annals of the New York Academy of Sciences 225, 38-45.

Kahane, I. \& Tully, J. G. (1976). Binding of plant lectins to mycoplasma cells and membranes. Journal of Bacteriology 128, I-7.

Lowry, O. H., Rosebrough, N. J., Farr, A. L. \& RANDALL, R. J. (195I). Protein measurement with the Folin phenol reagent. Journal of Biological Chemistry 193, 265-275.

NE'EMAN, Z. \& RAZIN, S. (1975). Characterization of the mycoplasma membrane proteins. V. Release and localization of membrane-bound enzymes in Acholeplasma laidlawii. Biochimica et biophysica acta $375,54-68$.

RAzIN, S. (1975). The mycoplasma membrane. In Progress in Surface and Membrane Science, vol. 9, pp. 257-312. Edited by D. A. Cadenhead, J. F. Danielli and M. D. Rosenberg. New York: Academic Press.

RAzIN, S. \& RotTem, S. (1976). Techniques for the manipulation of mycoplasma membranes. In Biochemical Analysis of Membranes, pp. 3-26. Edited by A. H. Maddy. London: Chapman and Hall.

Razin, S., Hasin, M., Ne'eman, Z. \& Rottem, S. (I973). Isolation, chemical composition, and ultrastructural features of the cell membrane of the mycoplasma-like organism Spiroplasma citri. Journal of Bacteriology 116, 142 I-I435.

Saglio, P., L'Hospital, M., Laflèche, D., Dupont, G., Bové, J. M., Tully, J. G. \& Freundt, E. A. (1973). Characterization of Spiroplasma citri gen. and sp.n.: a new mycoplasma-like organism associated with 'stubborn' disease of citrus. International Journal of Systematic Bacteriology 23, 19 I-204.

SEGREST, J. P. \& JACKSON, R. L. (1972). Molecular weight determination of glycoproteins by polyacrylamide gel electrophoresis in sodium dodecyl sulfate. Methods in Enzymology 28, 54-63.

SpIRO, R. G. (1972). Study of the carbohydrates of glycoproteins. Methods in Enzymology 28, 3-43. 